\title{
Editorial Introduction to the First Issue of Theory and Practice in Child Development
}

\author{
Nefise Semra Erkan*
}

* Editor-in-Chief of Theory and Practice in Child Development.

Department of Child Development, Faculty of Health Sciences, ìstanbul Gelisim University, Istanbul, Turkey.

E-mail: nserkan@gelisim.edu.tr

$$
10.46303 / \text { tpicd.2021.1 }
$$

\section{How to cite}

Erkan, N. S. (2021). Editorial Introduction to the First Issue of Theory and Practice in Child Development. Theory and Practice in Child Development, 1(1), i-iv. https://doi.org/10.46303/tpicd.2021.1

\section{Copyright license}

This is an Open Access article distributed under the terms of the Creative Commons Attribution 4.0 International license (CC BY 4.0).

\section{ABSTRACT}

This is the Editorial Introduction to the first issue of Theory and Practice in Child Development (T\&PICD). The T\&PICD is an international, open access, peer-reviewed journal devoted to child development related issues. This inaugural issue features five articles prepared by 14 authors. We would like to extend our appreciations to all who contributes by submitting or reviewing manuscripts or have been readers of T\&PICD. 


\section{EDITORIAL INTRODUCTION}

Dear Theory and Practice in Child Development (T\&PICD) readers and contributors,

We are excited to be with you through the inaugural issue of the T\&PICD journal. We would like to extend our appreciations to all who contributes by submitting or reviewing manuscripts or have been readers of $T \& P I C D$.

The T\&PICD is an international, open access, peer-reviewed journal devoted to child development related issues. The T\&PICD publishes research papers, theoretical works, literature reviews, research reports and book reviews on all aspects of child development. The overarching goal of the journal is to publicize original research findings that make significant contributions to the field of child development. The aim of the journal is to promote the work of academic researchers in every aspect of child development and its education.

The topics related to T\&PICD include but are not limited to:

- Child and adolescent developmental psychology

- Children's health care and pediatrics

- Child care and nursing

- Early childhood education

- Motor development

- Moral and character development

- Social and emotional development

- Cognitive development

- Communication and language development

- Parenting knowledge, attitudes, and practices

- Childhood illnesses

- Special education

- Disadvantaged children's studies

- Child and adolescent psychiatry

This inaugural issue features five articles prepared by 14 authors. The first contribution "Views of Kindergarten and First-Grade Teachers on School Readiness", by N. S. Erkan, N. Elkin, D. Kavgaoğlu, S. Ö. Dörterler and B. Kerigan, addresses the school readiness in early child education. The authors investigate the views of kindergarten and first-grade teachers on school readiness. They outline the importance of in-service training and seminars to increase the awareness of teachers and families about the importance of school readiness

N. Aral's "Visual Perception in Specific Learning Difficulties" focuses on the importance of visual perception in specific learning difficulties. The author argues that:

[..] configuring the education in accordance with the individual and developmental characteristics of these children and taking into account today's technological programs, instead of traditional teaching techniques, can help children gain academic skills, and at 
the same time contribute to the development of self-esteem and self-confidence of children and eliminate emotional and behavioral problems. (p. 36)

In "Investigation of Preschool Children's Perceptions to Protect the Environment Through Drawings", T. Kavaz, B. Kizgut-Eryilmaz, B. Polat, D. Amca-Toklu and F. Erbay explore the perceptions of 5 years old children attending preschool education about protecting the environment through drawings. They stated that:

[...] the most common perception of children to protect the environment was "not littering". [...] the children had different perceptions as "not wasting water", "not polluting nature", "not starting a fire", "not polluting the sea", and "not cutting the trees". [...] the children did not have a perception about some important concepts in environmental education as reuse, rethink, reflect, recycle, and redistribute dimensions.

(p. 49-50)

In "The Development of the Democratic Behavior Scale: A Validity and Reliability Study", S. Kent Kükürtcü, N. S. Erkan and Y. Seyfeli aimed to develop a scale to determine the democratic behavior levels of children in early childhood.

Finally, in the paper of C. Yıldız Taşdemir, titled "Is Scientific Creativity Possible in Early Childhood?", the scientific creativity in early childhood was conceptually and theoretically examined. This article provides an overview of studies examining scientific creativity in this period. The author concluded that "development of scientific creativity is possible in early childhood. Because both creativity and science-related skills begin to develop in the early years" (p. 6).

The T\&PICD Journal is seeking energetic, qualified, and high-profile researchers to join its Editorial Board team as associate editors or reviewers. The quality of a journal is reflective of the quality of its Editor(s) and Editorial Board members. In addition to our goal of providing free online access to the new journal, we also feel strongly about the necessity of its being very high in quality. A highly respected Editorial Board will go a long way toward establishing the initial credibility of the journal, which is particularly crucial in an experimental endeavor such as this, as well as helping to ensure the long-term quality of the final product. In choosing an Editorial Board, we are looking for researchers who are not just "well-known" but who have made significant research contributions. As someone whose contributions and technical judgement are highly regarded, you would be doing us a service by joining the Editorial Board. If you are interested in serving on the editorial board of the Journal, please let me know or you may suggest your colleagues who may be interested. If so, they can send their CV and letter of interest to this email address: editor@tpicd.org

Hereby, we would provide some details regarding the Editorial Board. The primary responsibility of Editorial Board members will be to review papers, thereby providing a consistent level of quality in the reviewing process. Ideally, papers will be reviewed by two members of the Editorial Board and one outside reviewer. In order to substantially reduce the 
time to publication in the T\&PICD Journal as compared to traditional journals, we have established the following policies for reviewing:

- Reviewers will be responsible for returning their reviews within 30 days after receiving the paper.

- Before reviewers are sent articles, they will be asked whether or not they have time to review the articles. Reviewers will be encouraged to accept papers only if they can realistically guarantee a response within three weeks. If a reviewer declines to review an article, this will NOT be considered anti-social, even if the reviewer has declined on several previous occasions.

- Editorial members will review two papers per year at most.

Additional roles of Editorial Board members:

- To advise the T\&PICD Journal policy and scope.

- To attract new and established authors and article submissions.

- To submit their own works.

- To work with the Editor-in-Chief to ensure ongoing development of the journal. Members of the Board may also take responsibility for key activities linked to the journal, such as the Book Review editor or Section Editor.

- Each Editorial Board member shall serve for a three-year term and may be reappointed.

Once again, I would like to thank everyone and express my special appreciation to the people who contributed to make this issue ready for you. I especially would like to thank all authors and reviewers for their contribution to the T\&PICD Journal. I hope you will both enjoy and be challenged by the articles in this issue of the T\&PICD Journal. I also look forward to seeing your contribution to the development of the T\&PICD Journal in the future. 